\title{
PENEGAKAN HUKUM PIDANA TERHADAP PRAKTIK PERJUDIAN BERKEDOK PERMAINAN ANAK-ANAK DI PUSAT PERBELANJAAN (MALL) DI KOTA PEKANBARU OLEH POLDA RIAU
}

\author{
Erdianto Effendi \\ Fakultas Hukum Universitas Riau \\ Email : erdianto.effendi@gmail.com
}

\begin{abstract}
According to the Explanation of Law No. 7 of 1974 Gambling is one of the ailments of a society that is united with evil. From the data handled by the Riau Regional Police, the most revealed gambling case is gambling under the guise of a children's play midfielder, which in practice is played by adults and contains elements of gifts. However, although some of them have been handled by Riau Regional Police Investigators, in the midst of the community we still encounter several games at the mall that can be qualified as gambling but towards those places as if they were untouched by law. This study concluded that law enforcement in the case of gambling under the guise of children's games in shopping centers in Pekanbaru City was not optimal. In carrying out law enforcement, law enforcers in this case the investigator faced with the constraints of differences in the interpretation of gambling with the Public Prosecutor and the lack of concrete gambling arrangements in the Criminal Code.
\end{abstract}

Keywords: Gambling, law enforcement

\begin{abstract}
Abstrak
Menurut Penjelasan UU No. 7 Tahun 1974 Perjudian adalah salah satu penyakit masyarakat yang manunggal dengan kejahatan. Dari data yang ditangani Polda Riau tersebut, kasus judi yang paling banyak diungkap adalah judi dengan kedok gelandang permainan anak-anak, yang di dalam praktiknya justru dimainkan orang dewasa dan mengandung unsur hadiah. Namun demikian, walaupun telah beberapa di antaranya ditangani oleh Penyidik Polda Riau, di tengah masyarakat masih kita jumpai beberapa permainan di mall yang dapat dikualifikasi sebagai judi namun terhadap tenpat-tempat tersebut seakan tidak tersentuh hukum. Penelitian ini menyimpulkan bahwa penegakan hukum atas kasus perjudian berkedok permainan anak-anak di pusat perbelanjaan di Kota Pekanbaru belum optimal. Dalam melakukan penegakan hukum, penegak hukum dalam hal ini penyidik berhadapan dengan kendala adanya perbedaan penafsiran judi dengan Jaksa Penuntut Umum dan tidak kongkretnya pengaturan judi dalam KUHP.
\end{abstract}

Kata kunci : Judi, penegak hukum 


\section{Pendahuluan}

\subsection{Latar Belakang Masalah}

Hukum pidana itu adalah hukum yang mengatur tentang kejahatan atau perbuatanperbuatan apa saja yang dapat dihukum dengan pidana yang ditentukan undang-undang, dan terhadap siapa saja pidana tersebut dapat dikenakan. ${ }^{1}$ Simons menyatakan bahwa yang dimaksud dengan hukum pidana adalah semua tindakan keharusan (gebod) dan larangan (verbod) yang dibuat oleh negara atau penguasa umum lainnya yang diancamkan dengan derita khusus, yaitu pidana. Moeljatno menyebutkan bahwa Hukum Pidana adalah bagian dari hukum yang mengadakan dasar dan aturan untuk menentukan perbuatanperbuatan mana yang tidak boleh dilakukan, yang dilarang dengan disertai ancaman sanksi berupa suatu pidana tertentu, bagi barangsiapa yang melanggar larangan tersebut, kapan dan dalam hal apa kepada mereka yang melanggar laranganlarangan itu dapat dikenakan atau dijatuhi pidana sebagaimana yang telah diancamkan, dan dengan cara bagaimana pengenaan pidana itu dapat dilaksanakan apabila ada orang yang melanggar larangan tersebut. ${ }^{2}$

KUHP Hindia Belanda yang mulai berlaku pada tahun 1918 meneladani Wetboek van Strafrecht Belanda tahun 1886. Meskipun KUHP yang berlaku pada waktu itu telah disesuaikan dengan kondisi masyarakat pada masa itu, namun pemikiran dasarnya tetap didasarkan pada alam pikiran Barat. ${ }^{3}$ Sebagai sebuah KUHP yang bersumber dari KUHP Belanda, maka pengaturan tentang keamanan negara mengacu sepenuhnya kepada KUHP Belanda dengan penyesuaian seperlunya.

Dalam negara Indonesia merdeka dan berdasarkan UU No. 1 Tahun 1946, dilakukan pergantian beberapa istilah dari sistem ketatanegaraan Hindia Belanda dengan ketatanegaraan Republik Indonesia, seperti istilah Gubernur Jenderal dalam KUHP diganti dengan istilah Presiden dan atau Wakil Presiden. Dalam Pasal VIII angka 12 UU No. 1 Tahun 1946 tangggal 26 Februari 1946, kata-kata de Koning, de regeererende Koningin of the Regent dalam rumusan Pasal 104 WvS diganti dengan kata-kata den President of den Vice President. ${ }^{4}$

Di Era Kemerdekaan telah banyak dilakukan usaha untuk menyesuaikan Kitab UndangUndang Hukum Pidana warisan kolonial dengan kedudukan Republik Indonesia sebagai negara merdeka dan dengan perkembangan kehidupan sosial lainnya, baik nasional maupun internasional. Dalam hal ini di samping pelbagai perubahan yang dilakukan melalui Undang-Undang Nomor 1 Tahun 1946 Jo. Undang-Undang Nomor 73 Tahun 1958, Kitab Undang-Undang Hukum Pidana telah beberapa kali mengalami pembaharuan dan/atau perubahan sebagai berikut:

1. Undang-Undang Nomor 1 Tahun 1960 tentang Perubahan Kitab Undang-Undang Hukum Pidana, yang menaikkan ancaman hukuman dalam Pasal-pasal 359, 360 dan 188 KUHP;

2. Undang-Undang Nomor 16 Prp. Tahun 1960 tentang Beberapa Perubahan Dalam Kitab Undang-Undang Hukum Pidana, yang merubah

\footnotetext{
Erdianto Effendi, Hukum Pidana Indonesia Suatu Pengantar, Refika Aditama, Bandung, 2011, hlm.9.

Sanusi Husin, Demokrasi Tidak Berhenti di Depan Pintu Gerbang Lembaga Pemasyarakatan, Pidato Pengukuhan Guru Besar Tetap IImu Hukum Pidana Fakultas Hukum Universitas Lampung, Bandar Lampung, 18 Oktober 1999, hlm.2. Lihat juga Moeljatno, Asas-asas Hukum Pidana, Jakarta : Rineka Cipta, 2008. hlm.17-18.

4 PAF Lamintang dan Theo Lamintang, Kejahatan terhadap Kepentingan Hukum Negara, Edisi Kedua, Jakarta : Sinar Grafika, 2010, hlm.5.
} 
kata-kata "vijf en twintig gulden" dalam Pasalpasal 364, 373, 379, 384 dan 407 ayat (1) Kitab Undang-Undang Hukum Pidana menjadi "duaratus lima puluh rupiah";

3. Undang-Undang Nomor 18 Prp Tahun 1960 tentang Perubahan Jumlah Hukuman Denda Dalam Kitab Undang-Undang Hukum Pidana dan Dalam Ketentuan Pidana Lainnya Yang Dikeluarkan Sebelum Tanggal 17 Agustus 1945;

4. Undang-Undang Nomor 2 PNPS Tahun 1964 tentang Tata Cara Pelaksanaan Pidana Mati Yang Dijatuhkan Oleh Pengadilan Dilingkungan Peradilan Umum dan Militer;

5. Undang-Undang Nomor 1 PNPS Tahun 1965 tentang Pencegahan Penyalahgunaan/Atau Penodaan Agama, yang antara lain telah menambahkan ke dalam KUHP Pasal 156a ;

6. Undang-Undang Nomor 7 Tahun 1974 tentang Penertiban Perjudian, yang merubah ancaman pidana dalam Pasal-pasal 303 ayat (1), 542 ayat (1) dan 542 ayat (2) Kitab Undang-Undang Hukum Pidana dan merubah sebutan Pasal 542 menjadi Pasal 303 bis.;

7. Undang-Undang Nomor 4 tahun 1976 tentang Perubahan dan Penambahan Beberapa Pasal Dalam Kitab Undang-Undang Hukum Pidana Bertalian Dengan Perluasan Berlakunya Ketentuan Perundang-Undangan Pidana, Kejahatan Penerbangan, dan Kejahatan Terhadap Sarana/Prasarana Penerbangan.;

8. Undang-Undang Nomor 27 Tahun 1999 tentang Perubahan Kitab Undang-Undang Hukum Pidana Yang Berkaitan Dengan Kejahatan Terhadap Keamanan Negara, khususnya berkaitan dengan kriminalisasi terhadap Penyebaran Ajaran Marxisme dan Leninisme;

9. Undang-Undang Nomor 3 Tahun 1971 yang kemudian digantikan oleh Undang-Undang Nomor 31 Tahun 1999 Jo. Undang-Undang Nomor 20 Tahun 2001, tentang Pemberantasan Tindak Pidana Korupsi, yang pada dasarnya menetapkan beberapa pasal dalam Kitab Undang-Undang Hukum Pidana yang berkaitan dengan Penyuapan dan Tindak Pidana Jabatan menjadi Tindak Pidana Korupsi. ${ }^{5}$

Dari 9 Undang-undang perubahan KUHP di atas, yang menjadi sorotan dalam hal ini adalah UU No. 7 Tahun 1974 tentang Penertiban Perjudian. Menurut Penjelasan UU No. 7 Tahun 1974 Perjudian adalah salah satu penyakit masyarakat yang manunggal dengan kejahatan, yang dalam prosessejarah dari generasi ke generasi ternyata tidak mudah diberantas. Perjudian terjadi di berbagai lingkungan masyarakat, sehingga perlu diusahakan agar masyarakat menjauhi melakukan perjudian, mulai dari lingkungan sekecil-kecilnya untuk menghindari ekses-ekses negatif yang lebih parah, untuk akhirnya berhenti melakukan perjudian. Maka untuk tujuan tersebut, pemerintah melakukan upaya untuk mengkalisifikasikan segala macam bentuk tindak pidana perjudian sebagai kejahatan, dan memberatkan ancaman hukumannya, karena ancaman hukuman yang terdapat di dalam KUHP dinilai belum maksimal dan tidak membuat pelakunya jera. Sehinggga pemerintah harus membuat regulasi yang baru mengenai tindak pidana perjudian sebagai penyempurnaan dari peraturan perundangundangan yang telah ada sebelumnya dengan - 
mengeluarkan UU No. 7 tahun 1974 tentang Penertiban Perjudian.

Definisi perjudian sebagaimana diatur dalam Pasal 303 ayat (3) adalah permainan dimana pada umumnya kemungkinan mendapat untung berggantung pada peruntungan belaka, juga karena pemainnya lebih terlatih atau mahir. Di situ termasuk segala pertaruhan tentang keputusan perlombaan atau permainan lainnya yang tidak diadakan antara mereka yang turut berlomba atau bermain, demikian juga segala pertaruhan lainnya.

Berbagai bentuk perjudian yang sudah sangat umum seperti Sie Jie, Togel, Mesin Jack Pot dan lain sebagainya telah banyak diungkapkan yang berujung pada pemidanaan para pelaku. Dalam tiga tahun terakhir, data pada Direktorat Reskrim Umum Polda Riau menunjukkan data sebagai berikut :

Tabel 1

Kasus Judi yang Ditangani Polda Riau dalam 3 tahun terakhir

\begin{tabular}{clc}
\hline No. & \multicolumn{1}{c}{ Tahun } & Jumlah Kasus \\
\hline 1. & 2012 & 6 \\
2. & 2013 & 5 \\
3. & 2014 (sampai Mei) & 5
\end{tabular}

\section{Sumber : Ditreskrimum Polda Riau}

Dari data yang ditangani Polda Riau tersebut, kasus judi yang paling banyak diungkap adalah judi dengan kedok gelandang permainan anak-anak, yang di dalam praktiknya justru dimainkan orang dewasa dan mengandung unsur hadiah. Namun demikian, walaupun telah beberapa di antaranya ditangani oleh Penyidik Polda Riau, di tengah masyarakat masih kita jumpai beberapa permainan di mall yang dapat dikualifikasi sebagai judi namun terhadap tenpat-tempat tersebut seakan tidak tersentuh hukum.

\section{Beberapa mall besar di Kota Pekanbaru yang} menggelar permainan berindikasi judi antara lain mall $\mathrm{P}, \mathrm{M}$ dan $\mathrm{C}$. Terhadap berbagai permainan yang berindikasi judi di mall-mall tersebut, pihak Polda Riau tidak bisa berbuat banyak jika tidak ada laporan atau keberatan dari masyarakat. Terhadap kasuskasus sudah dan sedang ditangani saja tidak semua kasus judi sampai ke Pengadilan. Hal itu terjadi karena adanya perbedaan pendapat antara Penyidik Polda Riau dengan pihak Jaksa Penuntut Umum tentang definisi dan unsur judi. Pasal 303 Ke 1 mengandung unsur : a) adanya pengharapan untuk menang, b) bersifat untung-untungan saja.c) ada insentif berupa hadiah bagi yang menang, dan d) pengharapan untuk menang semakin bertambah jika ada unsur kepintaran, kecerdasan dan ketangkasan. Penyidik berpandangan hadiah tidak mesti berbentuk uang sedangkan Penuntut Umum berpandangan bahwa unsur hadiah harus berbentuk uang. ${ }^{6}$

Kejaksaan sebagaimana wawancara dengan salah seorang Jaksa Penuntut Umum, Silfia Rosalina, $\mathrm{SH}, \mathrm{MH}$, memandang harus ada uang yang menjadi hadiah, atau setidaknya sesuatu yang dapat ditukar dengan uang. ${ }^{7}$ Jika mengacu kepada pendapat R. Soesilo dalam bukunya "KUHP Serta Komentar-Komentarnya Lengkap Pasal Demi Pasal menyebutkan bahwa permainan judi disebut juga "hazardspel". Yang biasa disebut sebagai "hazardspel" ialah misalnya main dadu, main selikuran, main jemeh, kodok-ulo, roulette, bakarat, kemping keles, kocok, keplek, tombola, dan lain-lain. Juga masuk totalisator pada pacuan kuda, pertan- 
dingan sepakbola, dsb. Tidak masuk "hazardspel" misalnya: domino, bridge, ceki, koah, pei, dsb yang biasa dipergunakan untuk hiburan. ${ }^{8}$

Perbedaan pandangan antara kejaksaan dan kepolisian tersebut diduga sebagai salah satu sebab utama belum maksimalnya penegakan hukum dan pemberantasan judi di Kota Pekanbaru khususnya dan Provinsi Riau umumnya. Berdasarkan hal tersebut, maka menarik untuk mengkaji bagaimana penegakan hukum terhadap kasus perjudian dengan kedok tempat permainan anak-anak dalam bentuk sebuah peneliitian dengan judul Penegakan Hukum Pidana Terhadap Praktik Perjudian Berkedok Permainan Anak-Anak Di Pusat Perbelanjaan (Mall) Di Kota Pekanbaru Oleh Polda Riau.

\subsection{Perumusan Masalah}

Bertitik tolak dari latar belakang di atas, maka masalah pokok dalam penelitian ini dapat dirumuskan sebagai berikut :

1. Bagaimanakah penegakan hukum terhadap praktik perjudian berkedok permainan anakanak di Pusat Perbelanjaan di Kota Pekanbaru oleh Polda Riau?

2. Kendala-kendala apakah yang dihadapi dalam penegakan hukum terhadap praktik perjudian berkedok permainan anak-anak di Pusat Perbelanjaan di Kota Pekanbaru oleh Polda Riau?

\subsection{Metode Penelitian}

a. Tipe Penelitian

Terdapat dua model penelitian dalam penelitian hukum yaitu penelitian hukum normatif yakni suatu penelitian yang bergantung pada data sekunder belaka dan penelitian hukum empiris yaitu penelitian hukum dengan cara melakukan identifikasi atas fakta hukum di tengah masyarakat.Penelitian hukum empiris setidaknya terdiri dari dua bentuk yaitu (1) penelitian terhadap identifikasi hukum (hukum tidak tertulis) dan (2) penelitian terhadap efektifitas hukum. ${ }^{9}$ Dalam penelitian tentang perjudian ini, digunakan metode penelitian hukum empiris khususnya penelitian terhadap efektifitas hukum.

\section{b. Lokasi Penelitian}

Yang menjadi objek penelitian ini adalah Kota Pekanbaru. Pemilihan Kota Pekanbaru sebagai sample dilakukan dengan metode area atau cluster sampling yaitu metode penentuan sample dengan menentukan terlebih dahulu beberapa area dari keseluruhan populasi. Adapun kriteria yang digunakan untuk menentukan sample dalam penelitian ini adalah dimana Polda Riau terletak di Kota Pekanbaru. Demikian juga mall-mall besar tersebut dalam latar belakang ada di Kota Pekanbaru.

\section{c. Sumber Data}

Untuk mengumpulkan data, peneliti melakukan studi kepustakaan (library research) dan study lapangan (field research). Studi kepustakaan dilakukan di beberapa pustaka guna mengumpulkan data sekunder dalam bentuk hukum primer seperti undang-undang, bahan hukum sekunder seperti buku-buku hukum dan bahan hukum tertier seperti jurnal hukum dan majalah, yang kesemuanya berfungsi sebagai -

8 R. Soesilo, Kitab Undang-Undang Hukum Pidana, (KUHP) serta Komentar-komentarnya Lengkap Pasal demi Pasal, Bogor : Politea, 1996, hlm. 222.

9 Soerjono Soekanto, Pengantar Penelitian Hukum, UI Press, Jakarta, 1986. HIm.51. 
informasi lini pertama (first line information).

Dalam studi lapangan, peneliti melakukan pengamatan terhadap sejumlah area permainan anak di sejumlah mall tersebut di atas, wawancara dengan pengelola area permainan di mall dan para pejabat yang bersangkutan dengan penegakan hukum perjudian. Penentuan sample dilakukan dengan metode purposive sampling.

Selain kepada para pemangku kepentingan, wawancara juga dilakukan dengan sejumlah anggota masyarakat yang menjadi pemain dalam sejumlah game yang berindikasi judi yang dilakukann dengan cara accidental sampling, yaitu mereka yang sedang melakukan permainan saat observasi dilakukan oleh peneliti.

\section{d. Tata Cara Sampling}

Penelitian berupa wawancara dilakukan untuk mendapatkan gambaran tentang proses penegakan hukum tindak pidana perjudian.

Dengan demikian, maka yang menjadi responden/sample dalam penelitian ini adalah sebagai berikut :

Tabel 2

Responden/Sample

\begin{tabular}{clc}
\hline No. & \multicolumn{1}{c}{ Populasi } & $\begin{array}{c}\text { Sample/Resp } \\
\text { onden }\end{array}$ \\
\hline 1. & $\begin{array}{l}\text { Kanit Judisila } \\
\text { Polda Riau }\end{array}$ & 1 orang \\
& $\begin{array}{l}\text { Jaksa Kejaksaan } \\
\text { 2. }\end{array}$ & Negeri Pekanbaru
\end{tabular}

\section{e. Alat Pengumpul Data}

Alat pengumpul data yang digunakan dalam penelitian ini adalah wawancara dengan pedoman wawancara yang telah disiapkan terlebih dahulu.

\section{f. Analisis Data}

Untuk menyimpulkan hasil penelitian guna mencapai hasil yang obyektif, data disusun, diklasifikasikan, dicatat dan dianalisa secara kualitatif. Penyusunan data bertujuan untuk menyeleksi data yang relevan dengan penelitian ini.

\section{Pembahasan}

\subsection{Pelaksanaan Penegakan Hukum atas Tindak}

\section{Pidana Perjudian di Polda Riau}

Dalam perspektif kriminologis, kebijakan atau upaya penanggulangan kejahatan pada hakikatnya merupakan bagian integral dari upaya perlindungan masyarakat (social defence) dan upaya mencapai kesejahteraan masyarakat (social welfare). Oleh karena itu dapat dikatakan bahwa tujuan akhir atau tujuan utama dari politik kriminal ialah perlindungan masyarakat.

Dalam usaha mencari kebenaran materil tersebut, haruslah ditempuh tahapan-tahapan dalam sistem peradilan pidana yang meliputi kegiatan penyelidikan, penyidikan, penuntutan, peradilan, dan pemasyarakatan. Penyelidikan merupakan tahap awal dari upaya mencari kebenaran materil terhadap suatu perkara pidana. Aparat penegak hukum haruslah menggunakan segala kewenangan yang dimilikinya untuk mengupayakan semaksimal mungkin kebenaran yang ingin ditemukan.

Penyelidikan merupakan salah satu cara atau metode atau sub daripada fungsi penyidikan yang mendahului tindakan lain, yaitu penindakan yang berupa penangkapan, penahanan, penggeledahan, 
penyitaan, pemeriksaan surat, pemanggilan, tindakan pemeriksaan dan penyerahan berkas kepada penuntut umum.

Penanggulangan kejahatan dapat ditempuh dengan :

a. penerapan hukum pidana (criminal law application);

b. pencegahan tanpa pidana (prevention without punishment) dan

c. mempengaruhi pandangan masyarakat mengenai kejahatan dan pemidanaan lewat media massa (influencing views of society on crime and punishment/mass media).

Upaya penanggulangan kejahatan secara besar dapat dibagi dua, yaitu lewat jalur "penal" (hukum pidana dan lewat jalur "non-penal" (bukan/di luar hukum pidana). Pembagian G.P. Hoefnagels di atas, upaya-upaya yang disebut dalam butir (b) dan (c) dapat dimasukkan dalam kelompok upaya "nonpenal".

Secara umum, diketahuinya suatu tindak pidana dapat terjadi dengan tiga hal yaitu, tertangkap tangan, laporan dan atau pengaduan. Dalam kasuskasus judi yang berkedok gelandang permainan di Kota Pekanbaru berdasarkan laporan dari masyarakat dan patroli yang dilakukan oleh penegak hukum baik Polda Riau maupun Polresta Pekanbaru. Namun demikian, pada umumnya sebagaimana yang disampaikan oleh Kompol Zulkarnain, penyidikan tindak pidana perjudian di wilayah Riau dilakukan oleh Polres dan Polresta di Riau dan jika dilakukan oleh Polres tetap dikoordinasikan oleh Polda Riau. ${ }^{10}$
Dalam tahun 2014 ini, Polda menangani 1 kasus dan Polresta Pekanbaru menangani 2 kasus. Kasus tersebut yaitu :

a. Kasus permainan berhadiah dengan menggunakan mesin yaitu dengan jenis permainan : mesin game jenis FISH HUNTER, KECOAK BULAT, JI HAI, HAPPY WORD, DEEP OCEAN, BUBLE / BUAYA, REVERIC CASTLE di Lantai III Mall P.

b. Kasus Permainan Mesin jenis Apple, Mahkota, Ikan, Naga, Tarzan, Kuda dan Poker yang terletak di M Game Center Pekanbaru oleh Polresta Pekanbaru.

c. Permainan berhadiah dengan menggunakan mesin yaitu dengan jenis permainan : Permainan tembak Ikan, Zuma, King Of Lion, Buble Win (BBW), Doraemon dan Odongodong yang terletak di arena tempat permainan anak-anak "G" Pekanbaru oleh Polda Riau. ${ }^{11}$

Walaupun berbeda tempat dan lokasi, namun pada umumnya permainan yang dimainkan sama seperti yang terjadi di Mall $P$ yaitu :

1. Mesin Apple di tempat permainan MP game centre adalah pertama, pemain membeli koin minimal seharga Rp 50.000 dan mendapatkan 10 koin, lalu koin tersebut dimasukkan ke dalam mesin, 1 koin menjadi 50 kredit poin, kemudian pemain menebak warna apel apa yang akan keluar (warna apel terdiri dari merah, hijau, biru, kuning) dengan menggunakan kredit poinnya, apabila gambar apel yang keluar sesuai dengan tebakan pemain maka kredit poinnya akan zertamabah, apabila tidak sesuai maka kredit poinnya akan berkurang, jika jumlah kredit poin

10 Wawancara dengan Kompol Zulkarnain, di Polda Riau tangggal 1 Nopember 2014.

11 Nama mall diinisialkan dan alamat sengaja tidak dicantumkan karena perkara ini masih diproses 
pemain sampai dengan 1000 kredit poin maka pemain dapat mengcancel kredit poinnya dan menukarkan dengan 1 lembar Voucher Telkomsel @Rp. 100.000,- (seratus ribu rupiah) kepada pihak games centre.

2. Permainan Mesin elektronik jenis Mahkota dengan cara : pemain membeli koin minimal seharga Rp 50.000 dan mendapatkan 10 koin, lalu koin tersebut dimasukkan ke dalam mesin, 1 koin menjadi 50 kredit poin, kemudian pemain menebak gambar apa yang akan keluar dengan menggunakan kredit poinnya, gambar di mesin mahkota terdiri dari burung, gajah, singa, panda, dan mahkota, apabila tebakan gambar pemain betul maka kredit poin didalam mesin akan bertambah apabila tidak sesuai maka kredit poinnya akan berkurang, Jika jumlah kredit poin pemain sampai dengan 1000 kredit poin maka pemain dapat mengcancel kredit poinnya dan menukarkan dengan 1 lembar Voucher Telkomsel @Rp. 100.000,- (seratus ribu rupiah) kepada pihak games centre.

3. Permainan Mesin elektronik Jenis Tarzan dengan cara : pemain membeli koin minimal seharga $\mathrm{Rp} 50.000$ dan mendapatkan 10 koin, lalu koin tersebut dimasukkan ke dalam mesin, 1 koin menjadi 50 kredit poin, kemudian pemain menebak gambar apa yang akan keluar dengan menggunakan kredit poinnya, gambar di mesin Tarzan terdiri dari Tarzan, burung kakatua, monyet, gajah, kambing, harimau, rusa, apabila tebakan gambar pemain betul maka kredit poin didalam mesin akan bertambah dan apabila tidak sesuai maka kredit poinnya akan berkurang, Jika jumlah kredit poin pemain sampai dengan 1000 kredit poin maka pemain dapat mengcancel kredit poinnya dan menukarkan dengan 1 lembar Voucher Telkomsel @Rp. 100.000,- (seratus ribu rupiah) kepada pihak games centre.

4. Permainan Mesin elektronik Jenis Buaya dengan cara : pemain membeli koin minimal seharga Rp 50.000 dan mendapatkan 10 koin, lalu koin tersebut dimasukkan ke dalam mesin, 1 koin menjadi 50 kredit poin, kemudian pemain menebak gambar dan warna apa yang akan keluar dengan menggunakan kredit poinnya, gambar terdiri dari Panda, gajah singa dan kucing, serta warna terdiri dari merah, kuning dan hijau, setelah kita memilih warna dan gambar maka bola kecil yang ada didalam mesin akan berputar dan berhenti di satu gambar yang berwarna, apabila tebakan pemain betul maka kredit poin didalam mesin akan bertambah dan apabila tidak sesuai maka kredit poinnya akan berkurang, Jika jumlah kredit poin pemain sampai dengan 1000 kredit poin maka pemain dapat mengcancel kredit poinnya dan menukarkan dengan 1 lembar Voucher Telkomsel @Rp. 100.000,- (seratus ribu rupiah) kepada pihak games centre.

5. Permainan Mesin elektronik Jenis Dinosaurus dengan cara : pemain membeli koin minimal seharga Rp 50.000 dan mendapatkan 10 koin, lalu koin tersebut dimasukkan ke dalam mesin, 1 koin menjadi 50 kredit poin, kemudian pemain menebak gambar apa yang akan keluar dengan menggunakan kredit poinnya, gambar di mesin Dinosaurus terdiri berbagai macam jenis dinosaurus, apabila tebakan gambar pemain - 
betul maka kredit poin didalam mesin akan bertambah dan apabila tidak sesuai maka kredit poinnya akan berkurang, Jika jumlah kredit poin pemain sampai dengan 1000 kredit poin maka pemain dapat mengcancel kredit poinnya dan menukarkan dengan 1 lembar Voucher Telkomsel @Rp. 100.000,- (seratus ribu rupiah) kepada pihak games centre.

6. Permainan Mesin elektornik jenis game Ikan dengan cara : pemain membeli koin minimal seharga Rp 50.000 dan mendapatkan 10 koin, lalu koin tersebut dimasukkan ke dalam mesin, 1 koin menjadi 50 kredit poin, kemudian pemain menggunakan kredit poinnya sebagai peluru untuk menembak gambar binatang laut yang ada didalam mesin, apabila binatang tersebut mati maka kredit poin didalam mesin bertambah dan apabila binatang itu tidak mati maka kredit poin di dalam mesin berkurang, Jika jumlah kredit poin pemain sampai dengan 1000 kredit poin maka pemain dapat mengcancel kredit poinnya dan menukarkan dengan 1 lembar Voucher Telkomsel @Rp. 100.000,- (seratus ribu rupiah) kepada pihak games centre.

7. Permainan Mesin elektornik jenis game Kuda dengan cara : pemain membeli koin minimal seharga Rp 50.000 dan mendapatkan 10 koin, lalu koin tersebut dimasukkan ke dalam mesin, 1 koin menjadi 50 kredit poin, kemudian pemain menebak gambar berupa kuda dan nomor dari 1 s/d 10 yang akan menang dengan menggunakan kredit poinnya, setelah kita menebak maka kuda tersebut akan berpacu di dalam mesin tersebut, apabila kuda yang kita tebak benar maka kredit poin didalam mesin akan bertambah dan apabila tidak sesuai maka kredit poinnya akan berkurang, Jika jumlah kredit poin pemain sampai dengan 1000 kredit poin maka pemain dapat mengcancel kredit poinnya dan menukarkan dengan 1 lembar Voucher Telkomsel @Rp. 100.000,- (seratus ribu rupiah) kepada pihak games centre.

Sedangkan permainan yang terdapat di Mall $G$ adalah sebagai berikut :

1. Mesin tembak Ikan. Cara memainkannya : Pemain harus membeli koin dari penyedia atau pengelola melalui kasir dengan harga 1 (satu) koin sejumlah Rp 2.000,- (dua ribu rupiah), selanjutnya pemain memasukkan koin-koin tersebut ke dalam mesin untuk mendapatkan kredit poin sesuai dengan jumlah koin yang telah dimasukan yakni sebanyak 1 (satu) koin dengan jumlah kredit poinnya adalah 500 (lima ratus) kredit poin. Setelah koin dimasukan, maka pemain memainkan permainan (game) tersebut yaitu menembak binatang yang muncul dilayar mesin game dengan cara menekan tombol. Pemain akan mendapat keuntungan berupa bertambahnya kredit poin jika pemain dapat menembak binatang tersebut sebanyak mungkin dengan tepat. Jika pemain tidak bisa menembak binatang tersebut dengan tepat, maka pemain akan kalah atau kredit poin milik pemain akan berkurang dan bisa habis.Terhadap kredit poin yang dimenangkan oleh pemain dapat ditukarkan dengan hadiah yang disediakan oleh pemilik atau pengelola tempat permainan sesuai dengan jumlah besaran kredit poin (poin) untuk sebuah hadiah. Dimana besaran jumlah kredit poin untuk sebuah hadiah tersebut ditentukan - 
oleh pemilik tempat. Kredit poin pada mesin ini mengeluarkan koin, bukan tiket/struk.

\section{Mesin Buble Win (BBW/Buaya/Tembak} Binatang). Cara memainkannya: Pemain harus membeli koin dari penyedia atau pengelola melalui kasir dengan harga 1 (satu) koin sejumlah $\operatorname{Rp} 2.000,-$ (dua ribu rupiah), selanjutnya pemain memasukkan koin-koin tersebut ke dalam mesin untuk mendapatkan kredit poin sesuai dengan jumlah koin yang telah dimasukan, dimana 1 (satu) koin memiliki jumlah kredit poin sebanyak 10 (sepuluh) kredit poin.Setelah koin dimasukan, maka pemain memainkan permainan (game) tersebut yaitu menembak binatang yang muncul dilayar mesin game dengan cara menekan tombol. Pemain akan mendapat keuntungan berupa bertambahnya kredit poin jika pemain dapat menembak binatang tersebut sebanyak mungkin dengan tepat. Jika pemain tidak bisa menembak binatang tersebut dengan tepat, maka pemain akan kalah atau kredit poin milik pemain akan berkurang dan bisa habis.Terhadap kredit poin yang dimenangkan oleh pemain dapat ditukarkan dengan hadiah yang disediakan oleh pemilik atau pengelola tempat permainan sesuai dengan jumlah besaran kredit poin (poin) untuk sebuah hadiah. Dimana besaran jumlah kredit poin untuk sebuah hadiah tersebut ditentukan oleh pemilik tempat. Kredit poin pada mesin ini mengeluarkan koin, bukan tiket/struk.

3. Mesin King Of Lion ( Tebak Binatang). Cara memainkannya : Pemain harus membeli koin dari penyedia atau pengelola melalui kasir dengan harga 1 (satu) koin sejumlah Rp 2.000,- (dua ribu rupiah), selanjutnya pemain memasukan koin-koin tersebut ke dalam mesin untuk mendapatkan kredit poin sesuai dengan jumlah koin yang telah dimasukan, dimana 1 (satu) koin memiliki jumlah kredit poin sebanyak 10 (sepuluh) kredit poin. Setelah koin dimasukan, maka pemain memainkan permainan (game) tersebut yaitu menebak bianatang yang ada dilayar mesin dengan cara menekan tombol. Kredit Poin akan bertambah jika pemain dapat menebak binatang tersebut sebanyak mungkin dengan tepat. Jika pemain tidak bisa menembak binatang tersebut dengan tepat, maka pemain akan kalah atau kredit poin milik pemain akan berkurang dan bisa habis.Terhadap kredit poin yang dimiliki pemain tersebut dapat ditukarkan dengan hadiah yang disediakan oleh pemilik atau pengelola tempat permainan sesuai dengan jumlah besaran kredit poin (poin) untuk sebuah hadiah. Dimana besaran jumlah kredit poin untuk sebuah hadiah tersebut ditentukan oleh pemilik tempat. Kredit poin pada mesin ini mengeluarkan koin, bukan tiket/struk.

4. Mesin ZUMA (Tebak Binatang). Cara memainkannya : Pemain harus membeli koin dari penyedia atau pengelola melalui kasir dengan harga 1 (satu) koin sejumlah Rp 2.000,(dua ribu rupiah), selanjutnya pemain memasukan koin-koin tersebut ke dalam mesin untuk mendapatkan kredit poin sesuai dengan jumlah koin yang telah dimasukan, dimana 1 (satu) koin memiliki jumlah kredit poin sebanyak 10 (sepuluh) kredit poin.Setelah koin dimasukan, maka pemain memainkan permainan (game) - 
tersebut yaitu menebak bianatang yang ada dilayar mesin dengan cara menekan tombol. Kredit Poin akan bertambah jika pemain dapat menebak binatang tersebut sebanyak mungkin dengan tepat. Jika pemain tidak bisa menembak binatang tersebut dengan tepat, maka pemain akan kalah atau kredit poin milik pemain akan berkurang dan bisa habis.Terhadap kredit poin yang dimiliki pemain tersebut dapat ditukarkan dengan hadiah yang disediakan oleh pemilik atau pengelola tempat permainan sesuai dengan jumlah besaran kredit poin (poin) untuk sebuah hadiah. Dimana besaran jumlah kredit poin untuk sebuah hadiah tersebut ditentukan oleh pemilik tempat. Kredit poin pada mesin ini mengeluarkan koin, bukan tiket/struk.

5. Mesin Paman (Tebak Buah). Cara memainkannya : Pemain harus membeli koin dari penyedia atau pengelola melalui kasir dengan harga 1 (satu) koin sejumlah Rp 2.000,(dua ribu rupiah), selanjutnya pemain memasukan koin-koin tersebut ke dalam mesin untuk mendapatkan kredit poin sesuai dengan jumlah koin yang telah dimasukan, dimana 1 (satu) koin memiliki jumlah kredit poin sebanyak 50 (lima puluh) kredit poin.Setelah koin dimasukan, maka pemain memainkan permainan (game) tersebut yaitu menebak gambar buah yang ada dilayar monitor dengan cara menekan tombol. Kredit Poin akan bertambah jika pemain dapat menebak gambar suatu buah yang sama dengan tepat sebanyak maksimal 6 jenis buah yang sama. Jika pemain tidak bisa menembak binatang tersebut dengan tepat, maka pemain akan kalah atau kredit poin milik pemain akan berkurang dan bisa habis. Terhadap kredit poin yang dimiliki pemain tersebut dapat ditukarkan dengan hadiah yang disediakan oleh pemilik atau pengelola tempat permainan sesuai dengan jumlah besaran kredit poin (poin) untuk sebuah hadiah. Dimana besaran jumlah kredit poin untuk sebuah hadiah tersebut ditentukan oleh pemilik tempat. Terhadap mesin game ini, kredit poin yang dimenangkan oleh pemain akan dihitung dengan sejumlah tiket/struk. Banyak sedikitnya tiket/struk yang keluar dari mesin game tergantung dengan jumlah kredit poin yang dimenangkan oleh pemain. Semakin banyak kredit poin, maka semakin banyak juga tiket/sruk yang akan keluar. Kemudian tiket/struk tersebut ditukarkan dengan hadiah. Kredit poin pada mesin ini mengeluarkan tiket/struk, bukan koin.

6. Mesin Odong-odong (Permainan anak-anak). Cara memainkannya: Pemain harus membeli koin dari penyedia atau pengelola melalui kasir dengan harga 1 (satu) koin sejumlah Rp 2.000,(dua ribu rupiah), selanjutnya pemain memasukan koin-koin tersebut ke dalam mesin. Setelah koin dimasukan, pemain kemudian menaiki atau duduk diatas mesin tersebut, dan mesin tersebut akan bergerak maju mundur, ditempat. Permainan ini tidak dapat memerlukan penukaran koin dengan hadiah, karena permainan ini adalah permainan menghabiskan waktu saja. Tidak memiliki kredit poin dan tidak mengeluarkan koin ataupun tiket/struk. Limit waktu permainan ini adalah selama 5 menit untuk satu koin. 
Sedangkan permainan yang dilaksanakan di Plaza $D$ adalah sebagai berikut :

1. Fish Hunter yaitu: Pertama, pemain membeli coin, coin tersebut dimasukkan kedalam mesin game, setelah itu mesin game bisa dimainkan, yang mana coin tersebut akan menjadi credit poin, kredit poin tersebutlah yang dimainkan manjadi umpan peluru untuk membunuh jenis ikan yang akan ditembak, apabila ikan tersebut sampai mati makan kredit poin akan bertambah, apabila ikan yang ditembak tidak mati maka kredit poin berkurang. Adapun jumlah ikan yang ikan akan ditembak atau yang dikejar kurang lebih sebanyak 100 ekor ikan, dan setiap ikan tidak sama besar dan mempunyai kredit poin yang berbeda - beda, nilai kredit poin paling besar adalah 500 kredit poin dan paling kecil 10 kredit poin, 1 (satu) keping koin mempunyai nilai kredit poin sebanyak 10 (sepuluh) poin. Setiap ikan mempunyai warna yang berbeda - beda, untuk membunuh ikan-ikan tersebut mempunayi cara yang sama yaitu menekan tombol yang terletak di meja mesin dan dilakukan secara berulang - ulang sampai ikan mati.

2. KECOAK BULAT, cara memainkannya : Memasukkan koin kedalam mesin game yang akan dimainkan, koin tersebut akan menjadi kredit poin dan kredit poin tersebut yang digunakan untuk bermain, jenis permainan yang ada didalam mesin yaitu, singa, buaya, kelinci, yang mana setiap memainkan bisa memasukkan minimal 1 (satu) keping koin dan akan mendapatkan 10 (sepuluh) kredit poin yang mana pemain mempunyai dua kali kesempatan untuk menekan tombol yang tersedia di meja mesin dan setelah pemain menakan tombol, maka jarum mesin akan berputar searah dengan jaraum jam, apa bila jarum jam tersebut berhenti di gambar sesuai dengan pilihan pemain maka pemin akan mendapatkan kredit poin sebanyak 50 kredit poin, apabila jarum tersebut tidak sesuai dengan pilihan pemain makan pemain dianggap kalah dan nilai kredit poin akan berkurang.

3. JI HAl, cara memainkannya : Apabila pemain memasukkan 1 keping koin kedalam mesin, maka pemain akan memperoleh 10 (sepuluh) kredit poin, selanjutnya pemain akan mengarahkan stick untuk mencari sasaran ikan yang akan ditembak dan apabila sasaran sudah pas dengan yang inginkan maka pemain akan menekan tombol yang tersedia dimeja mesin untuk menembak ikan tersebut sampai mati, untuk satu kali tembak maka poin akan berkurang sebanyak 2 kredit poin, apabila ikan sudah mati maka pemain akan mendapatkan hadiah kredit poin sebanyak kurang lebih $10 \mathrm{~s} / \mathrm{d}$ 50 kredit poin.

4. HAPPY WORD, cara memainkannya : pertama pemain memasukkan minimal satu keping koin, maka pemain akan mendapatkan nilai sebanyak 100 kredit poin, selanjutnya pemain bebas memilih salah satu dari 9 (sembilan) tombol yang tersedia di meja mesin tersebut, setelah tombol ditekan maka lampu akan nyala dan berputar serah jarum jam, apabila lampu tersebut berhenti berputar dan menunjuka kesalah satu ke gambar yang dipilih pemain makan pemain dianggap menang, maka kredit pemain akan bertambah sebanyak kurang lebih 6 s/d 100 
kredit poin, apabila lampu berhenti tidak sesuai dangan pilihan pemain, maka kredit poinnya akan berkurang.

5. DEEP OCEAN, cara memainkannya: Memasukkan koin kedalam mesin, koin akan menjadi kredit poin, 1 (Satu) keping koin akan mendapatkan kredit poin senilai 10 kredit poin, selanjutnya pemain mempunyai kesempatan untuk memilih salah satu tombol bergambar daari 8 (delapan) tombol yang ada, yang bergambar jenis hewan laut, setelah tombol ditekan, maka pemain akan menunggu waktu kurang lebih selam 2 menit, maka dua ekor jenis ikan hiu akan keluar dan akan memakan 8 (delapan) jenis laut tersebut, apabila salah satu dari 8 jenis hewan laut tidak makan oleh kedua ekor ikan hiu sesuai dengan pilihan pemain, maka pemain dianggap menang dan akan mendapatkan nilai kredit poin 40 s/d 200 kredit poin, apabila pilihan tersebut maka pemain kalah dan kredit poin akan berkurang.

6. BUBLE / BUAYA, cara memainkannya : pertama masukkan koin kedalam mesin, minimal 1 (satu) keping koin dan koin akan menjadi kredit poin, 1 (satu) keping koin akan mempunyai nilai 10 (sepuluh) kredit poin, setelah pemain menakan tombol, maka bola akan berputar searah dengan jarum jam, apa bila bola tersebut berhenti di gambar sesuai dengan pilihan pemain maka pemin dinyakan menang dan akan mendapatkan kredit poin sebanyak $10 \mathrm{~s} / \mathrm{d} 100$ kredit poin, apabila bola berhenti tidak sesuai dengan pilihan pemain makan pemain dianggap kalah dan nilai kredit poin akan berkurang.
7. REVERIC CASTLE, cara memainkannya : pertama masukkan koin kedalam mesin, minimal 2 (dua) keping koin, maka pemain akan memperoleh 1 (satu) kesempatan dengan waktu bermain hanya 30 detik untuk memainkan mesin tersebut dengan cara, pemain akan mengarahkan stick untuk memilih hadiah yang tersedia didalam mesin tersebut, yaitu hadiah berupa : HP Merk NOKIA, SAMSUNG, JAM TANGAN, DII, apabila pemain selama 30 datik tersebut pemain berhasik mendorong salah satu hadiah yang tersedia didalam mesin,maka hadiah tersebut akan menjadi milik pemain, apabila adalam waktu 30 detik, pemain tidak berhasil mendorong kelobang yang tersedia maka pemain dianggap kalah dan akan memulainya dari awal lagi dengan memasukkan dua keping koin lagi, dan seterusnya.

Jenis-jenis permainan tersebut pada umumnya juga disediakan oleh gelandang permainan di mall dan arena tempat belanja lainnya, namun penyidik tidak dapat berbuat karena untuk melakukan patroli dan operasi penangkapan memerlukan biaya yang tidak sedikit sementara setelah dilakukan proses hukum, kasus tersebut tidak dapat diproses lebih lanjut karena terdapat perbedaan persepsi dengan Jaksa Penuntut Umum.

Menurut keterangan Silfia Rosalina, $\mathrm{SH}, \mathrm{MH}$, tiga kasus tersebut direkomendasikan oleh JPU untuk dihentikan karena tidak terpenuhi unsur. Menurut JPU unsur hadiah yang harus dipenuhi dalam tindak pidana perjudian adalah adanya hadiah berupa uang. Hadiah berupa selain uang tidak dapat diketegorikan telah memenuhi unsur tindak pidana perjudian. ${ }^{12}$

12 Wawancara dengan Silfi Rosalina, SH,MH, Jaksa di Kejati Riau tanggal 10 Nopember 2014 
Di pihak pengelola tempat permainan mereka mendalilkan bahwa apa yang mereka lakukan tidak menyalahi hukum karena berdasarkan izin pejabat yang berwenang seperti dalam kasus game di MP adalah sebagai berikut :

1. TDUP Nomor 093 /BPT/IV /2013 yang diterbitkan oleh BPT Kota pekanbaru tanggal 30 April 2013

2. IZIN Gangguan Nomor 17 /BPT/IV/2013 tanggal 21 April 2013

3. Surat Izin Keramaian Yang dikeluarkan Sat Intelkam Polresta Pekanbaru.

4. Surat Pemeriksaan Alat Proteksi Pemadan Kebakaran. ${ }^{13}$

Menurut penulis, izin sebagaimana yang dikemukakan oleh pengelola tersebut memang benar adanya dan sah secara hukum. Namun izin tersebut bukan untuk izin perjudian melainkan izin permainan anak-anak. Kalau dalam praktik, terdapat permainan judi, maka itu tidak menghapuskan melawan hukum dari adanya permainan judi dalam arena permainan yang seharusnya diperuntukkan bagi anak-anak.

\subsection{Kendala dalam Penegakan Hukum Tindak Pidana Perjudian di Polda Riau}

Menurut Arief Gosita, dalam mencari faktorfaktor yang menyebabkan terjadinya kejahatan terdapat beberapa teori dalam ilmu kriminologi. Beberapa teori tersebut antara lain :

1. Teori Biologic Criminal, yaitu teori yang mengungkapkan penyebab kejahatan dari sisi biologis si pelaku kejahatan.

2. Teori Psikologis dan Psikiatris (Psicologic Criminal), yaitu penyebab kejahatan yang bersumber dari masalah kejiwaan pelaku.
3. Teori Socio Cultural, yaitu teori yang mengungkapkan penyebab kejahatan karena faktor-faktor sosiologis dan kultural. ${ }^{14}$

Menurut Ridwan Hasibuan, berdasarkan teori antropologis yang mengatakan bahwa orang melakukan kejahatan itu adalah tergantung pada individunya. Orang melakukan kejahatan memang sudah ada dari dalam pribadinya sendiri sebagai seorang jahat. Berdasarkan teori sosiologis sebab orang melakukan kejahatan karena dipengaruhi atau ditentukan oleh lingkungan sekitarnya, baik lingkungan alam maupun lingkungan masyarakatnya. ${ }^{15}$

Dari dua teori tersebut maka muncul teori ketiga yaitu teori bio-sosiologis. Aliran ini mengatakan bahwa sebab orang melakukan kejahatan karena faktor individu yang bersangkutan ditambah dengan adanya pengaruh lingkungan. Bahwa semua perbuatan manusia itu adalah hasil dari unsur-unsur individu ditambah lingkungan. Khusus untuk kejahatan maka aliran ini mengemukakan rumus :

Dari dua teori tersebut maka muncul teori ketiga yaitu teori bio-sosiologis. Aliran ini mengatakan bahwa sebab orang melakukan kejahatan karena faktor individu yang bersangkutan ditambah dengan adanya pengaruh lingkungan. Bahwa semua perbuatan manusia itu adalah hasil dari unsur-unsur individu ditambah lingkungan. Khusus untuk kejahatan maka aliran ini mengemukakan rumus :

$$
\mathrm{K}=\mathrm{I}+\mathrm{L}
$$

Kejahatan $=$ Individu + Lingkungan

13 Wawancara dengan Silfi Rosalina, SH,MH, Jaksa di Kejati Riau tanggal 10 Nopember 2014

14 Wawancara dengan MT, Pengelola Mall Pekanbaru, tanggal 12 Nopember 2014

15 Arif Gosita, Kriminologi, Akademika Pressindo, Jakarta, 1995, hal.43. 
Di dalam I tersebut termasuklah seluruh unsur fisik dan psikis, dan dalam $L$ tersebut termasuklah unsur lingkungan alam dan lingkungan sosial masyarakat di sekitarnya. ${ }^{16}$ Dengan memperhatikan aliran tersebut maka dapatlah disimpulkan bahwa timbulnya kejahatan disebabkan oleh dua faktor yaitu faktor orang atau individu dan kedua faktor lingkungan.

Menurut Mardjono Reksodiputro, dalam kriminologi kritis dikatakan bahwa gejalan kejahatan merupakan suatu konstruksi sosial yaitu pada waktu suatu masyarakat menetapkan bahwa sejumlah perilaku dan orang dinyatakan sebagai kejahatan. Dengan demikian kejahatan dan penjahat bukanlah gejala yang secara bebas dan objektif dapat dipelajari para ilmuwan, karena gejala tersebut hanya ada jika ditentukan demikian oleh masyarakat. ${ }^{17}$

Beberapa indikasi untuk menilai pelaksanaan ketentuan peraturan perundangundangan umumnya didasarkan pada teori penegakan hukum yang dikemukakan Soerjono Soekanto yang mengemukakan bahwa penegakan hukum senantiasa dipengaruhi oleh faktor-faktor seperti hukum itu sendiri, faktor penegak hukum, faktor sarana prasarana, faktor masyarakat, dan faktor budaya masyarakat. ${ }^{18}$

1) Faktor Hukum itu sendiri.

Perundang-undangan tentang judi khususnya dalam KUHP bersifat multi tafsir, padahal kaedah hukum pidana sebagai bidang hukum yang paling keras, seharusnya tidak memuat tindak pidana yang bersifat abstrak dan multi tafsir.

Pengertian judi seharusnya dirumuskan dalam undang-undang secara kongkret sehingga tidak menyerahkan penafsiran kepada penegak hukum di lapangan.

2) Faktor Penegak Hukum.

Dalam penanganan masalah judi, terdapat perbedaan pandangan antara penyidik dengan JPU, karena itu apa yang menurut penyidik adalah judi, di hadapan JPU belum tentu judi. Dengan demikian, banyak perkara yang ditangani polisi tidak diteruskan ke pengadilan karena menurut JPU tidak terpenuhi unsur judinya.

3) Faktor masyarakat.

Di tengah masyarakat judi dianggap sebagai hal yang biasa saja jika tidak menimbulkan hadiah berupa uang. Pertaruhan di tengah masyarakat dianggap tidak melawan hukum kecuali yang dipertaruhkan adalah berupa uang. Bahkan dalam masyarakat tertentu, judi dianggap ibadah atau ritual agama. Karena itu sulit dilakukan penegakan hukum atas kasus judi.

Namun dalam masyarakat Kota Pekanbaru yang berjiwakan nilai budaya Melayu, judi seharusnya dilarang, namun terhadap judi berkedok permainan anak-anak di pusat perbelanjaan sulit ditertibkan karena masyarakat sebagai konsumen banyak menggunakannya.

\section{Kesimpulan}

Berdasarkan pembahasan pada sebelumnya dapat disimpulkan sebagai berikut :

\section{Kesimpulan}

Berdasarkan pembahasan pada sebelumnya dapat disimpulkan sebagai berikut :

1. Penegakan hukum atas kasus perjudian berkedok permainan anak-anak di pusat

16 Wawancara dengan Silfi Rosalina, SH,MH, Jaksa di Kejati Riau tanggal 10 Nopember 2014 
94 Erdianto Effendi, Penegakan Hukum Terhadap Praktik Perjudian....

perbelanjaan di Kota Pekanbaru belum optimal.

2. Dalam melakukan penegakan hukum, penegak hukum dalam hal ini penyidik berhadapan dengan kendala adanya perbedaan penafsiran judi dengan Jaksa Penuntut Umum dan tidak kongkretnya pengaturan judi dalam KUHP.

\section{DAFTAR PUSTAKA}

Effendi, Erdianto. Hukum Pidana Indonesia Suatu Pengantar. Bandung: Refika Aditama, 2011.

Gosita, Arif. Kriminologi. Jakarta: Akademika Pressindo, 1995.

Husin, Sanusi. Demokrasi Tidak Berhenti di Depan Pintu Gerbang Lembaga Pemasyarakatan. Bandar Lampung: Pidato Pengukuhan Guru Besar Tetap IImu Hukum Pidana Fakultas Hukum Universitas Lampung, 1999.
Lamintang, PAF dan Theo Lamintang. Kejahatan terhadap Kepentingan Hukum Negara, Edisi Kedua. Jakarta: Sinar Grafika, 2010.

Soekanto, Soerjono. Pengantar Penelitian Hukum. Jakarta: UI Perss, 1986.

Soesilo, R. Kitab Undang-Undang Hukum Pidana, (KUHP) serta Komentar-komentarnya Lengkap Pasal demi Pasal. Bogor: Politea, 1996. 